\title{
Occurrence and bioaccumulation of chemical contaminants in lettuce grown in peri-urban horticulture
}

\author{
Anna Margenat ${ }^{\mathrm{a}}$, Víctor Matamoros ${ }^{\mathrm{a},}$, Sergi Díez ${ }^{\mathrm{a}}$, Núria Cañameras ${ }^{\mathrm{b}}$, Jordi Comas $^{\mathrm{b}}$, Josep M. Bayona ${ }^{\mathrm{a}}$ \\ ${ }^{a}$ Department of Environmental Chemistry, IDAEA-CSIC, c/Jordi Girona, 18-26, E-08034 Barcelona, Spain \\ ${ }^{\mathrm{b}}$ Department of Agri-Food Engineering and Biotechnology, UPC, Esteve Terrades 8, Building 4, E-08860 Castelldefels, Spain
}

\section{A R T I C L E IN F O}

Article history:

Received 6 March 2018

Received in revised form 3 May 2018

Accepted 3 May 2018

Available online xxx

Editor: D. Barcelo

Keywords:

Peri-urban

Horticulture

Indirect reuse

Wastewater

Trace elements, organic microcontaminants

\begin{abstract}
A B S T R A C T
Peri-urban horticulture performs environmental and socio-economic functions and provides ecological services to nearby urban areas. Nevertheless, industrialization and water pollution have led to an increase in the exposure of peri-urban vegetables to contaminants such as trace elements (TEs) and organic microcontaminants (OMCs). In this study, the occurrence of chemical contaminants (i.e., 16 TEs, 33 OMCs) in soil and lettuce leaves from 4 farm fields in the peri-urban area of the city of Barcelona was assessed. A rural site, outside the peri-urban area of influence, was selected for comparison. The concentration of TEs and OMCs ranged from non-detectable to $802.5 \mathrm{mg} / \mathrm{kg} \mathrm{dw}$ and from non-detectable to $397 \mu \mathrm{g} / \mathrm{kg} \mathrm{dw}$ respectively in the peri-urban soil, and from $6 \cdot 10^{-5}$ to $4.91 \mathrm{mg} / \mathrm{kg}$ fw and from non-detectable to $193 \mu \mathrm{g} / \mathrm{Kg}$ fw respectively in lettuce leaves. Although the concentration of $\mathrm{Mo}, \mathrm{Ni}, \mathrm{Pb}$, and $\mathrm{As}$ in the soil of the peri-urban area exceeded the environmental quality guidelines, their occurrence in lettuce complied with human food standards (except for $\mathrm{Pb}$ ). The many fungicides (carbendazim, dimetomorph, and methylparaben) and chemicals released by plastic pipelines (tris(1-chloro-2-propyl)phosphate, bisphenol $\mathrm{F}$, and 2-mercaptobenzothiazole) used in agriculture were prevalent in the soil and the edible parts of the lettuce. The occurrence of these chemical pollutants in the peri-urban area did not affect the chlorophyll, lipid, or carbohydrate content of the lettuce leaves. PCA (Principal Component Analysis) showed that soil pollution, fungicide application, and irrigation water quality are the most relevant factors determining the presence of contaminants in crops.
\end{abstract}

\section{Introduction}

Peri-urban horticulture performs environmental and socio-economic functions and provides ecological services to nearby urban areas. These include fresh vegetables with a low carbon footprint, as well as the provision of recreational, landscape structure, and other ecological services (Van Veenhuizen, 2007). Nevertheless, peri-urban agriculture is exposed to atmospheric and water pollution. For instance, air pollution associated with transportation infrastructure (airports, harbors, highways) or the use of reclaimed water containing organic microcontaminants (OMCs) and trace elements (TEs) for irrigation lead to their accumulation in soil and potentially in plants (Colon and Toor, 2016; Liacos et al., 2012). In particular, the application of manure and biosolids for soil amendment and of reclaimed water for irrigation have been reported as the main sources of OMCs in agriculture (Eggen and Lillo, 2012).

On the other hand, as water scarcity is increasing due to climate change and population growth, the application of reclaimed water for crop irrigation in peri-urban agriculture is becoming a reliable alternative water supply, especially in arid and semi-arid regions (WHO, 1989). Despite the widespread occurrence of OMCs such as pharmaceuticals or personal care products in reclaimed water, their concen-

\footnotetext{
Corresponding author.

Email address: vmmqam@cid.csic.es (V. Matamoros)
}

trations are generally low, ranging from $\mathrm{ng} / \mathrm{L}$ to $\mu \mathrm{g} / \mathrm{L}$; their continual release into the environment coupled with their transformation products makes them behave in a "pseudo-persistent" way (Daughton and Ternes, 1999). Reclaimed water irrigation is also one of the main sources of TEs in agriculture, along with biosolid and manure amendments and atmospheric deposition (Liacos et al., 2012; Lough et al., 2005; Nabulo et al., 2006). As a result, TEs have a significant impact on peri-urban agriculture (Singh and Kumar, 2006).

Bioaccumulation of OMCs have been frequently observed in crops grown under field conditions irrigated with treated wastewater $(\mathrm{Wu}$ et al., 2014). The highest concentrations have been detected in the edible parts of leafy vegetables (carbamazepine and its metabolites at $347 \mathrm{ng} / \mathrm{g} \mathrm{dw}$ lettuce) rather than in root or fruit-bearing vegetables (Riemenschneider et al., 2016). Knowledge about the bioaccumulation of OMCs in vegetables irrigated with treated wastewater under field conditions is scarce (Calderón-Preciado et al., 2011). One long-term study (3 consecutive years) revealed that a longer duration of treated wastewater irrigation may lead to a significant uptake and bioaccumulation of some OMCs (Christou et al., 2017). Moreover, TEs such as $\mathrm{Pb}, \mathrm{Cd}$, and $\mathrm{Zn}$ have been found at greater concentrations in crops grown on the roadside in peri-urban areas than in those from rural sites (Nabulo et al., 2010, 2006). Therefore, concerns regarding human exposure to OMCs and TEs have arisen as they have been detected in the edible parts of plants (Khan et al., 2008; Pan et al., 2014). However, only field studies can fully assess the incorporation of these compounds in real scenarios (Colon and Toor, 2016), and to 
date few such studies exist (Malchi et al., 2014; Wu et al., 2014). Another important adverse effect of the use of reclaimed water in agriculture is its high nitrate content. Nitrate content in vegetables is the major human dietary source of nitrate, and $5 \%$ of ingested nitrate is transformed into the toxic form nitrite (Santamaria, 2006). In this regard, nitrate fertilization and the reuse of treated wastewater contribute to nitrate uptake by food crops (Castro et al., 2009).

The occurrence of TEs and OMCs in agricultural soils can also lead to morphological and physiological changes in the exposed plants. For instance, Hurtado et al. (2017) observed that the occurrence of OMCs in irrigation waters at environmentally relevant concentrations resulted in a decrease in the chlorophyll content, morphological changes, and alterations in the metabolic profile of lettuces. Carter et al. (2015) observed a reduction in biomass productivity and changes in hormone and nutrient content in zucchini due to the presence of carbamazepine and verapamil at environmentally relevant concentrations $\left(0.005-10 \mathrm{mgL}^{-1}\right.$ in soil). The occurrence of heavy metals such as $\mathrm{Pb}$ in plants can inhibit chlorophyll biosynthesis and decrease vegetable carbohydrate content (Gaweda, 2007; Peralta-Videa et al., 2009), while the occurrence of Cd can cause lipid peroxidation (Monteiro et al., 2007; Rodríguez-Serrano et al., 2006). However, there is no available information about the impact of the co-occurrence of OMCs and TEs in crops in real-life scenarios. Furthermore, although the occurrence of TEs and pesticide residues in food products is regulated in the EU (EFSA), USA (FDA), China, and Australia-New Zealand, and the FAO has published international guidelines (Codex Alimentarius), no regulations exist for the other detected OMCs.

In a previous study, several chemical pollutants were detected in irrigation waters from the peri-urban horticultural area of the city of Barcelona (Margenat et al., 2017). The present paper aims to assess the occurrence of these pollutants (16 TEs and 33 OMCs) in lettuce cultivation (soils and plants), as well as bioaccumulation factors and their potential impacts on leaf constituents (i.e. chlorophyll, nitrates, lipids, and carbohydrate content). The study was conducted in 4 farm fields located in the peri-urban area of Barcelona (NE Spain) and a remote organic farming plot located in a rural area.

\section{Material and methods}

\subsection{Sampling site description}

Five locations in the Llobregat River delta and its lower valley (NE Spain) were sampled. This peri-urban area consists of 3300 ha of protected farmland in the metropolitan area of the city of Barcelona that is furrow-irrigated by open air channels (P2-P4, Fig. 1) built in the early 19th century (Paül and McKenzie, 2013). It is characterized by a gradient of atmospheric and irrigation water pollution originating from industrial, urban, and agricultural activities.

The sampling sites included four farm plots located in the peri-urban area (P2-P5, Fig. 1) and one at a rural site (P1, Fig. 1), each with a surface area of $>0.1$ ha. The soil of all 5 sampling sites was sufficiently fertile to grow vegetables, and all had a similar electrical conductivity and $\mathrm{pH}$ (Margenat et al., 2017).

Most of the sampling sites (P2-P4) were irrigated with water from the Llobregat River, which receives discharges from 80 urban and industrial wastewater treatment plants (WWTPs) that account, on average, for $18 \%$ of the total river flow (Marcé et al., 2012). The irrigation water is then distributed through open-air concrete channels (P2-P4). The irrigation water for P3 in particular comes from the Infanta Channel, which is an effluent-dominated creek receiving effluents from 10 WWTPs. The P5 sampling site is irrigated with well water impacted by industrial and road runoff, and the rural site (P1) is irrigated with well and rainwater. A drip irrigation system is used at the reference site (P1), while furrow irrigation (P2-P4) and sprinkler irrigation (P5) is applied at the other sites. The reference site is also the

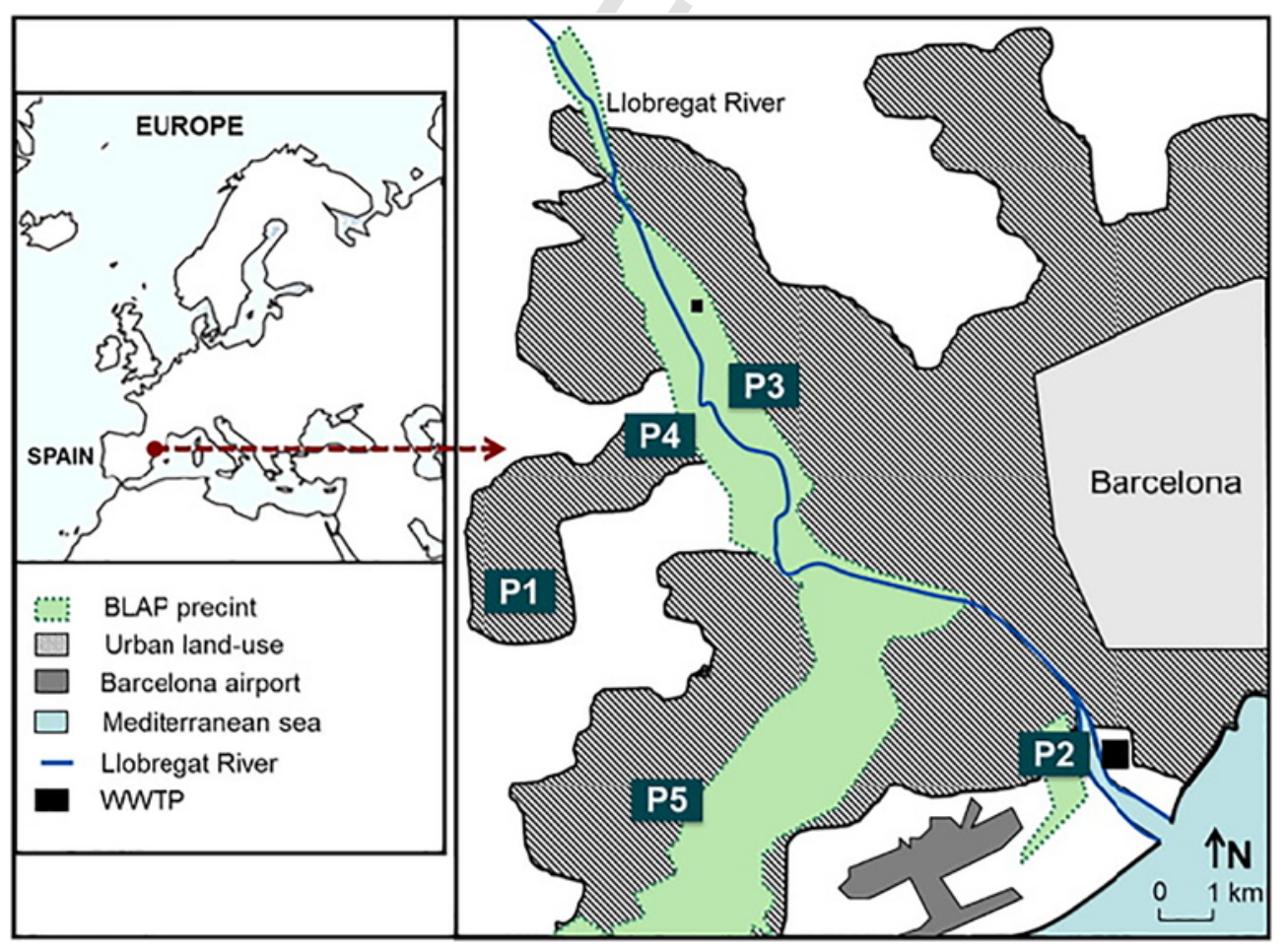

Fig. 1. Map of the sampling area. P1. Begues; P2. Prat de Llobregat P3. Sant Joan Despí; P4. Sant Boi de Llobregat; P5. Viladecans. 
only one dedicated to organic farming. Further information is available in Margenat et al. (2017).

\subsection{Sampling strategy}

\subsubsection{Soil}

Soil was sampled in May of 2016 when the lettuce was harvested. A composite soil sample from a horizon of 0 to $20 \mathrm{~cm}$ was obtained from five subsamples in each farm plot. Soil samples were sieved through a $2.0 \mathrm{~mm}$ mesh and stored at $-20^{\circ} \mathrm{C}$. According to the USDA (1987) classification, soil samples from farm plots P1, P3, and P4 were loamy sand, while the soils from farm plots P2 and P5 were sandy. The soil samples were also characterized by UNE-EN ISO/IEC 17025:2005 accredited laboratories. Table 1-SM provides information about the physicochemical properties of each of the studied soils.

\subsubsection{Lettuce}

Lettuce was selected for being one of the most cultivated vegetables in the peri-urban agricultural area of Barcelona. The lettuces (Lactuca sativa L. cv. Batavia) were harvested when they reached their commercial size. The lettuce seedlings were planted in February-March and June 2016, and the plants were harvested in May 2016 (P1-P5) and June 2016 (P3-4) for the winter and summer seasons respectively (Fig. 1). Each farm field was divided in 5 sections, and 10 lettuces were collected per section. For each section, a quarter of each lettuce was mixed and comminuted together using liquid nitrogen and a porcelain mortar. These samples were then stored at $-20^{\circ} \mathrm{C}$ until they were analyzed. Thus, 5 samples were obtained per plot.

\subsection{Analytical procedures}

The chemicals and reagents used for the analytical methodologies described below are listed in the supplementary material (SM) section.

\subsubsection{Nitrate content in lettuce}

Extraction was performed according to the procedure recommended by the AOAC (Guadagnin et al., 2005). Briefly, $40 \mathrm{~mL}$ of Milli-Q water were added to a tube containing $5 \mathrm{~g}$ of fresh-weight ( $\mathrm{fw}$ ) lettuce leaves, and it was heated to $70^{\circ} \mathrm{C}$ for $15 \mathrm{~min}$. Once the extract was at room temperature, Milli-Q water was added to a total volume of $100 \mathrm{~mL}$. It was then filtered through a filter paper (Whatman No. 4) prior to spectrophotometric measurement. Nitrate content was measured with a Hach-Lange spectrophotometer (DR 1900 Portable Spectrophotometer) at a wavelength of $460 \mathrm{~nm}$ as nitrate nitrogen $\left(\mathrm{NO}_{3}-\mathrm{N}\right)$.

\subsubsection{Lipids and carbohydrate extraction in lettuce leaves}

The method was adapted from that described by Yang et al. (2016). Extraction was carried out by adding $15 \mathrm{~mL}$ of ethanol/hexane $(1: 1, \mathrm{v} /$ v) to a glass tube with $3 \mathrm{~g}$ of fw sample. The sample was sonicated for $15 \mathrm{~min}$ and centrifuged at $2500 \mathrm{rpm}$ for $15 \mathrm{~min}$. It was then filtered through a $0.22 \mu \mathrm{m}$ nylon filter (Scharlab, Barcelona, Spain) into a pre-weighed glass tube. After removing the solvent by purging and drying with nitrogen gas, the tube and filter were weighed. The sample remaining in the tube was operationally defined as lipid content, whereas the sample on the filter was operationally defined as carbohydrates.

\subsubsection{Chlorophyll content in lettuce}

Chlorophyll content in lettuce was measured with a chlorophyll meter (CCM200Plus, Opti-Sciences) (Hudson, NH, USA) in triplicate based on the outer and inner leaf absorbance of each head of lettuce. A calibration curve was obtained to relate the chlorophyll content to the absorbance previously measured with the chlorophyll content meter. To this end, rounded samples of leaves ( $4 \mathrm{~cm}$ diameter) were extracted with $5 \mathrm{~mL}$ of $N, N$-dimethylformamide (DMF) and kept in the dark at $4{ }^{\circ} \mathrm{C}$ for $48 \mathrm{~h}$ before the spectrophotometric determination. The extracts were measured at two wavelengths, 647 and $664.5 \mathrm{~nm}$, so that chlorophylls (a, b, and total) could be calculated using Inskeep and Bloom's coefficients (Inskeep and Bloom, 1985; Porra, 2002).

\subsubsection{Trace element (TE) extraction}

\subsubsection{Soil}

A slightly modified pseudo-total digestion method (Lee et al., 2006) using a strong acid $\left(\mathrm{HNO}_{3}-\mathrm{HClO}_{4}\right)$ was used. A portion of $0.1 \mathrm{~g}$ of homogenized, dried sample was sieved through $2 \mathrm{~mm}$ mesh (CISA, Spain) and placed in a polyethylene tube. Then, $10 \mathrm{~mL}$ of $65 \% \mathrm{HNO}_{3}$ and $10 \mathrm{~mL}$ of concentrated $\mathrm{HClO}_{4}$ were added, and the mix was heated up to $135^{\circ} \mathrm{C}$ for $16 \mathrm{~h}$. The digested samples were then evaporated, resuspended with $3 \mathrm{~mL}$ of $\mathrm{HNO}_{3}$, and then heated to ensure dissolution. A $1 \mathrm{~mL}$ aliquot was diluted with $24 \mathrm{~mL}$ of Milli-Q water, and the sample was filtered $(0.2 \mu \mathrm{m})$ prior to analysis.

An inductively coupled plasma optical emission spectrometer (Thermo Scientific, iCAP 6500 ICP-OES) and an inductively coupled plasma mass spectrometer (Thermo Scientific, XSeries 2 ICP-MS) were used for the determination of major and minor TEs respectively in both the soil and lettuce samples. The content of $\mathrm{Hg}$ was determined using an advanced mercury analyser (AMA-254, Altec, Prague, Czech Republic).

\subsubsection{Lettuce}

A portion of $1 \mathrm{~g}$ of plant leaf tissues, dried and sieved, was digested with $4 \mathrm{~mL}(1: 1) \mathrm{HNO}_{3}$ and $10 \mathrm{~mL}$ of $(1: 4) \mathrm{HCl}$ in a closed Teflon vessel using a six-position EvapoClean heating block (EvapoClean, Deltalabo, France) at $95^{\circ} \mathrm{C}$ for at least 3 hosed. Afterwards, samples were transferred to a $100-\mathrm{mL}$ volumetric flask and centrifuged; therefore, a $10 \mathrm{~mL}$ aliquot was diluted with $40 \mathrm{~mL}$ Milli-Q water prior to analysis. The determination method was the same as for the soil, but values are expressed in fw basis. The applied methodology was validated by NIST 1570a (Gaithersburg, USA), with certified values for $\mathrm{As}, \mathrm{B}, \mathrm{Cd}, \mathrm{Co}, \mathrm{Cu}, \mathrm{Mn}, \mathrm{Hg}, \mathrm{Ni}, \mathrm{Zn}$ in lettuce. For accuracy, excellent extraction efficiencies were noted for these elements (92-107\%). Further information is provided in Section 2.1 of the SM.

\subsubsection{Organic microcontaminant (OMC) extraction}

Physicochemical properties (molecular weight, pKa, solubility, and $\log \mathrm{K}_{\mathrm{OW}}$,) of the studied OMCs are provided in Table 2-SM.

\subsubsection{Soil}

Soil extraction was adapted from a previously reported method (Xu et al., 2008). Briefly, $5 \mathrm{~g}$ of soil (fw), homogenized and sieved through $2.0 \mathrm{~mm}$ mesh, were placed in a glass tube. It was fortified with $31.25 \mathrm{ng}$ of a mixture of 6 surrogates and left to equilibrate for $30 \mathrm{~min}$. The extraction was performed by sonication for $15 \mathrm{~min}$ three times with $5 \mathrm{~mL}$ of acetone/ethyl acetate $(1: 1, \mathrm{v} / \mathrm{v})$. The extract was then centrifuged at $3100 \mathrm{rpm}$ for $10 \mathrm{~min}$ and the supernatants were 
combined and evaporated to ca. $0.5 \mathrm{~mL}$ under a gentle stream of nitrogen. Next, $2 \mathrm{~mL}$ of methanol were added to the final extract, which was reconstituted with $250 \mathrm{~mL}$ of deionized water prior to percolation through previously conditioned SPE cartridges (STRATA X, $100 \mathrm{mg}$, $6 \mathrm{~mL}$ ). The cartridges were dried under vacuum and eluted with $10 \mathrm{~mL}$ of ethyl acetate. The extracts were concentrated to ca. $250 \mu \mathrm{L}$ under a stream of nitrogen and $37.25 \mathrm{ng}$ of triphenylamine (TPhA) were added as an internal standard. Finally, a $50 \mu \mathrm{L}$ aliquot was analyzed by GC-MS/MS without derivatization, and another $50 \mu \mathrm{L}$ aliquot was analyzed derivatized with $10 \mu \mathrm{L}$ of TMSH. The analytical quality parameters (LOD, LOQ, and recoveries) are provided in Tables 3-5 in the SM section.

\subsubsection{Lettuce}

The extraction of OMCs from plant leaf tissues was performed according to Calderón-Preciado et al. (2009). Briefly, the extraction of samples $(0.5 \mathrm{gfw})$ was performed with a matrix solid-phase dispersion method previously spiked with $12.5 \mathrm{ng}$ of a mixture of surrogates and equilibrated for $30 \mathrm{~min}$. Neutral-basic and acid fractions were obtained by solvent partitioning at neutral and acid $\mathrm{pH}$, respectively. After clean-up, fractions were reduced to ca. $80 \mu \mathrm{L}$ and $37.25 \mathrm{ng}$ of TPhA were added. A $50 \mu \mathrm{L}$ aliquot and another one derivatized with $10 \mu \mathrm{L}$ of TMSH were analyzed in GC-MS/MS. The extraction of carbamazepine and 10,11-epoxycarbamazepine from lettuce samples was carried out by sonication followed by liquid chromatography tandem mass spectrometry (LC-MS/MS). To this end, $0.5 \mathrm{~g}$ of fw lettuce was spiked with $50 \mathrm{ng}$ of carbamazepine $-{ }^{13} \mathrm{C}$ and left to stand for $30 \mathrm{~min}$. Samples were sonicated with $10 \mathrm{~mL}$ of $\mathrm{MeOH}$ for $15 \mathrm{~min}$ and centrifuged $15 \mathrm{~min}$ at $3000 \mathrm{rpm}$. The extraction was performed twice and the extracts were combined and reduced to ca. $1 \mathrm{~mL}$ with nitrogen gas and reconstituted with $10 \mathrm{~mL}$ of LiChrosolv water. The samples were then percolated through SPE cartridges (STRATA X, $100 \mathrm{mg} \cdot 6 \mathrm{~mL}$ ), previously conditioned with $1 \mathrm{~mL}$ of $\mathrm{MeOH}$ and water, respectively. The cartridges were washed with water/methanol (95:5, $\mathrm{v} / \mathrm{v})$ and eluted with $2 \mathrm{~mL}$ of a mixture of $\mathrm{MeOH} /$ ethyl acetate $(1: 1$, $\mathrm{v} / \mathrm{v})$. The final extracts were reduced almost to dryness, resuspended in $1 \mathrm{~mL}$ of water, and filtrated $(0.22 \mu \mathrm{m})$ prior to LC-MS/MS analysis. The LODs and LOQs were calculated for each analyte as three and ten times the signal from the baseline noise ( $\mathrm{S} / \mathrm{N}$ ratio), respectively. Analytical quality parameters (LOD, LOQ, and recoveries) are provided in Tables 6-8 in the SM section. Further details on the GC-MS/MS and LC-MS/MS are provided elsewhere (SM Sections 2.2 and 2.3).

\subsection{Data analysis}

Data values for the soil and plants are presented in dw and fw respectively. This is in agreement with legislated units for each of the studied matrices. The bioconcentration factor $(\mathrm{BCF})$ was calculated for TEs and OMCs as the ratio between the concentrations in the edible parts of lettuce plants and soil content (Eq. (3)). The units used were $\mathrm{mg} / \mathrm{kg} \mathrm{dw}$ for TEs and $\mu \mathrm{g} / \mathrm{kg} \mathrm{dw}$ for OMCs.

$$
=\frac{\text { concentration in edible part of plant }\left(\mathrm{mg} \cdot \mathrm{kg}^{-1} \mathrm{dw}\right)}{\text { concentration in soil }\left(\mathrm{mg} \cdot \mathrm{kg}^{-1} \mathrm{dw}\right)}
$$

The experimental results were statistically evaluated using the SPSS v. 22 package (Chicago, IL, US). All data sets were checked for normal distribution using the Kolmogorov-Smirnov test to ensure that parametric statistics were applicable. The comparison of means of the occurrence of chemical pollutants between farm plots was performed with a two-paired (Wilcoxon) signed-rank test (the concentration of each compound was compared between farm plots). Principal Component Analysis (PCA) was conducted on the concentration levels of TEs, OMCs, lettuce constituents (chlorophyll, nitrates, lipids, and carbohydrates), and soil properties. Once the data matrix had been completed, it was autoscaled to have zero mean and unit variance (correlation matrix). Statistical significance was defined as $p \leq 0.05$.

\section{Results and discussion}

\subsection{Occurrence of trace elements (TEs)}

\subsubsection{Soil}

Table 1 shows the concentration of 16 TEs in the soil samples and their corresponding maximum values established for agricultural use by Catalan Law 5/2017 in accordance with Spanish Royal Decree 9/ 2005. The TE concentrations ranged from non-detectable (Cd in all plots except P3) to $802 \mathrm{mg} / \mathrm{kg} \mathrm{dw}$ (Mn in P5). The most abundant TEs were $\mathrm{Mn}, \mathrm{Ba}, \mathrm{Cr}, \mathrm{Pb}, \mathrm{Zn}, \mathrm{Cu}$, and $\mathrm{B}$ in all the sampling sites. The total median concentration of TEs per site was as follows: $824 \mathrm{mg} /$ $\mathrm{kgdw}$ (P1), $1353 \mathrm{mg} / \mathrm{kg} \mathrm{dw}$ (P2), $1518 \mathrm{mg} / \mathrm{kg} \mathrm{dw}$ (P3), $1623 \mathrm{mg} / \mathrm{kgdw}$ (P4), and $1896 \mathrm{mg} / \mathrm{kg} \mathrm{dw}$ (P5). Based on these results, P1 was thus the least polluted site, and P5 the most polluted. A two-paired test showed that soil from the rural site (P1) was less polluted by TEs than any of the soils from the peri-urban area of Barcelona (P2-P5, $p<0.05)$. In fact, the concentration of $\mathrm{Mo}, \mathrm{Ni}, \mathrm{Pb}, \mathrm{Zn}$, and $\mathrm{As}$ in the soils of the peri-urban area (P2-P5) exceeded the maximum soil concentration limit established for agricultural use in the regional decree (Generalitat de Catalunya, 2017). These results are consistent with the abundance of Mn (103-13,584 mg/kg dw), Zn (23-214 mg/kg dw), Cr (12-57 mg/ $\mathrm{kg} \mathrm{dw}), \mathrm{Ni}(9-111 \mathrm{mg} / \mathrm{kg} \mathrm{dw}), \mathrm{Cu}(4-170 \mathrm{mg} / \mathrm{kg} \mathrm{dw}), \mathrm{Cd}(0.1-130 \mathrm{mg} /$ $\mathrm{kg} \mathrm{dw})$, and $\mathrm{Pb}(20-86 \mathrm{mg} / \mathrm{kg} \mathrm{dw})$ reported in soil from the Baix Llobregat area (Zimakowska-Gnoińska et al., 2000). Finally, the high concentration of As in the peri-urban soil was in agreement with the fact that phosphatic fertilizers generally contain the highest concentrations of most heavy metal(loid)s including As, Cd, U, Th and $\mathrm{Zn}$ (Alloway, 2012), whereas in the rural site organic amending was used for soil fertilization.

The high concentration levels of $\mathrm{Pb}$ are consistent with the fact that, in the past, $\mathrm{Pb}$ particles were widely released into the environment through vehicle emissions from leaded gasoline engines (half-

Table 1

Concentration of TEs $(\mathrm{mg} / \mathrm{kg} \mathrm{dw})$ in the agricultural soil from the different studied plots. The generic reference levels (GRL, $\mathrm{mg} / \mathrm{kg} \mathrm{dw}$ ) of these elements for contaminated soils in Catalonia are shown.

\begin{tabular}{lllllll}
\hline & Plot 1 & Plot 2 & Plot 3 & Plot 4 & Plot 5 & GRL agricultural use \\
\hline $\mathrm{B}$ & 92.1 & 131.7 & 93.9 & 80.9 & 58.0 & - \\
$\mathrm{Ba}$ & 86.3 & 257.0 & 226.3 & 304.5 & 411.7 & 500 \\
$\mathrm{Cd}$ & $<0.56$ & $<0.56$ & 0.79 & $<0.50$ & $<0.60$ & 2.5 \\
$\mathrm{Co}$ & 5.7 & 11.1 & 9.7 & 10.3 & 16.9 & 25 \\
$\mathrm{Cr}$ & 25.5 & 42.3 & 44.6 & 43.5 & 62.2 & 400 \\
$\mathrm{Cu}$ & 33.3 & 68.3 & 88.9 & 177.8 & 89.2 & - \\
$\mathrm{Li}$ & 10.1 & 27.4 & 25.6 & 28.1 & 43.2 & - \\
$\mathrm{Mn}$ & 361.0 & 439.3 & 520.4 & 494.4 & 802.5 & - \\
$\mathrm{Mo}$ & 2.0 & 3.7 & 3.6 & 2.0 & 2.9 & 3.5 \\
$\mathrm{Ni}$ & 16.9 & 30.9 & 57.0 & 32.5 & 48.9 & 45 \\
$\mathrm{~Pb}$ & 14.7 & 83.0 & 216.2 & 163.8 & 77.4 & 60 \\
$\mathrm{Rb}$ & 28.4 & 35.0 & 37.1 & 39.2 & 57.6 & - \\
$\mathrm{Sb}$ & $<0.56$ & $<0.56$ & $<0.54$ & $<0.50$ & $<0.60$ & 6.0 \\
$\mathrm{Zn}$ & 131.7 & 195.4 & 148.1 & 208.2 & 198.2 & 170 \\
$\mathrm{As}$ & 16.2 & 27.3 & 45.3 & 38.1 & 27.3 & 30 \\
$\mathrm{Hg}$ & 0.012 & 0.301 & 0.372 & 0.374 & 0.191 & 2 \\
\hline
\end{tabular}


life in soil of about 53,000 years). Industrial emissions and paints can also contribute to the release of $\mathrm{Pb}$ into the environment (Nabulo et al., 2006). Ba and Mn come mainly from natural sources in both urban and rural areas (Davis et al., 2009), while the source of B can be either geogenic or anthropogenic (fertilizers, households detergents, discharges from industrial plants, etc.) (Pedrero et al., 2010). Finally, $\mathrm{Zn}$ is naturally present in all soils in concentrations typically ranging from $10 \mathrm{mg} / \mathrm{kg}$ to $100 \mathrm{mg} / \mathrm{kg}$; and human activities have enriched them through atmospheric deposition, fertilizers, and sewage sludge (Alloway, 2012). The proximity of road networks can also lead to considerable exposure to $\mathrm{Zn}$ through brake and tire wear, tailpipe emissions of motor oil, and anti-wear additives (Lough et al., 2005).

\subsubsection{Lettuce}

Table 2 shows the minimum, maximum, and median concentrations $(\mathrm{mg} / \mathrm{kg} \mathrm{fw})$ of TEs in lettuce samples. B, Ba, Mn, and $\mathrm{Zn}$ were the most abundant TEs, in keeping with the occurrence of these elements in soil samples (Table 1). The detected levels were in the same range as those published for garden-grown vegetables (leafy greens, herbs, roots, and fruits) (McBride et al., 2014) for $\mathrm{Ba}(3.7 \mathrm{mg} / \mathrm{kg} \mathrm{fw}$ ) and $\mathrm{Cd}(0.028 \mathrm{mg} / \mathrm{kg} \mathrm{fw})$, but slightly higher for $\mathrm{Pb}(0.099 \mathrm{mg} / \mathrm{kg} \mathrm{fw})$. The values of Cd were compliant with Commission Regulation (EC) No 1881/2006 of 19 December 2006, which sets maximum levels for certain contaminants in food stuffs. In contrast, $\mathrm{Pb}$ in P3 in the summer season slightly exceeded the maximum legislated concentration. Since the winter levels were below the regulated concentrations, further studies are needed to establish the significance of these data.

A two-paired test was used to compare differences between sampling points regarding the TEs present in lettuce samples. No statistical differences $(p>0.05)$ were obtained for $\mathrm{Cr}, \mathrm{Mn}$, or Ba content at the study sampling sites. In contrast, they were obtained among sites for the rest of the TEs. The most polluted crops were found in site P3 (total concentration of $192 \mathrm{mg} / \mathrm{kg}$ fw in winter and $170 \mathrm{mg} / \mathrm{kg}$ fw in summer), whereas crops least polluted by TEs (total concentration $140 \mathrm{mg} / \mathrm{kg} \mathrm{fw}$ ) were grown in the rural farm plot. Nevertheless, no statistical differences were found in the total metal concentration measured in vegetable crops from each farm plot $(p>0.05)$.

\subsubsection{Bioconcentration factor for TEs}

Table 9-SM shows the BCFs of selected TEs in lettuce for each of the studied farm plots. The BCFs ranged from 0.0002 (As in P5) to 1.78 (Cd in $\mathrm{P} 2)$. Sb and Cd were the TEs with the highest BCFs. Ratios $>1$ denote a positive accumulation of metals in plant organs. Only $\mathrm{Cd}$ (P2 and P4) and Sb (P1, P2, P3, and P5) exhibited values above 1. Although most of the values obtained were $<1$, it must be recalled that only the edible part of the plant was analyzed. The BCF of a TE depends on the plant cultivated and the soil properties, such as $\mathrm{pH}$, $\mathrm{OMC}$, and the distribution of metals in different soil fractions (Kos et al., 2003). These results are in keeping with other studies in which $\mathrm{Cd}$ is the TE most likely to accumulate in leafy vegetables, with BCFs ranging from 0.01 to 3.10 (Chang et al., 2014).

\subsection{Occurrence of organic microcontaminants (OMCs)}

\subsubsection{Soil}

Table 3 shows that only 25 of the 33 OMCs studied in the sampled agricultural soils were detected over the LOQs in at least one site. Unexpectedly, the concentrations of OMCs ranged from non-detectable to $397 \mathrm{ng} / \mathrm{g} \mathrm{dw}$ for TCPP (P1). The highest concentration values were recorded for TCPP and bisphenol F (Plots 1 and 5). The high values of TCPP and BPF could be due to the use of plastic tubing for drip and sprinkler irrigation. In fact, TCPP is used as a raw material in the manufacture of polyester, plastic foam, binder, and resins, while bisphenol $\mathrm{F}$ and other bisphenol analogues have gradually emerged as substitutes for bisphenol A in various applications, such as the plastic and canning industries, due to their similar physicochemical properties (Regueiro and Wenzl, 2015). The concentrations of OMCs detected in the soils of the area of study were in the same range as those published in the peri-urban horticultural area of La Plata (Buenos Aires, Argentina) for azoxystrobin $(0.8-153 \mathrm{ng}$ / $\mathrm{gdw}$ ) and lower than those for chlorpyrifos (79-2258 ng/g dw) (Mac Loughlin et al., 2017). The average concentration of OMCs in soil was higher in P1 and P5 $(>14 \mathrm{ng} / \mathrm{gdw})$ than in P2-P4 $(<4 \mathrm{ng} / \mathrm{gdw})$. This is probably due to the use of plastic tubing for water irrigation in these two farm plots. Paired $t$-tests showed statistical differences $(p<0.05)$ in all the sites.

\subsubsection{Lettuce}

Table 4 shows that 8 of the 25 compounds detected in soil samples were above the LOQs in the lettuce samples. Similarly, as in the agricultural soil, methylparaben (106-193 ng/g fw in P1), 2-mercaptobenzothiazole (2.39-40.5 ng/g fw in P1) and bisphenol F (17.8-104 ng/ $\mathrm{g} f \mathrm{w}$ in $\mathrm{P} 3$ ) were among the ones detected at highest concentrations. Whereas the occurrence of bisphenol F and 2MBT can be attributed to the presence of plastic materials in the agricultural fields (pipelines or plastic mulch or film), the high abundance of MPB may be due to its use as a fungicide in agriculture, although it can also be biosynthesized by some plants (Calvo-Flores et al., 2018). MPB is also released into water bodies via domestic and industrial wastewater (Becerra-Herrera et al., 2018). Fungicides, dimethomorph, and carbendazim were only detected in winter in P3 and P5, at concentrations up to $39 \mathrm{ng} / \mathrm{g} \mathrm{fw}$ (Table 4). This is consistent with the need for an early application of fungicide in winter to reduce downy mildew and lettuce drop disease. Hence, direct foliar application of these fungicides could be the main source of their presence in lettuce crops. These results are higher than the concentration levels at which carbendazim has been detected in lettuce $(2-7 \mathrm{ng} / \mathrm{g} \mathrm{fw})$ sold at farmers' markets from January to March in Hatay (Turkey) (Esturk et al., 2014). In addition, carbamazepine, one of the most widely reported pharmaceuticals in crops due to its high plant uptake, and its transformation product (epoxy-carbamazepine) were detected in almost all the farm plots. This is in keeping with the results reported by Malchi et al. (2014), where carbamazepine and epoxy-10,11-carbamazepine were detected in carrots and sweet potatoes irrigated with secondary treated wastewater under field conditions.

In summary, although previous studies have reported the occurrence of 33 OMCs in the irrigation waters (Margenat et al., 2017), only two were taken up by plants from the water (i.e. carbamazepine and surfynol 104). Therefore, this study shows that the occurrence of OMCs in irrigation waters is not the main source of OMCs in crops, as other pollutants released by the irrigation system or pesticide applications (carbendazim, dimetomorph, 2MBT, BPF, and MPB) were detected in higher concentrations. Based on the two-paired test, it was concluded that the concentrations of OMCs in groundwater irrigated vegetables (P1 and P5) are statistically different $(p<0.05)$ from those observed in surface water irrigated crops (P2 to P4). Higher occurrence of $2 \mathrm{MBT}$ in groundwater irrigated crops $(\mathrm{P} 1)$ can be attributed to the use of drip and sprinkle irrigation, whereas the higher occurrence of MPB is of unknown origin. Conversely, although BPF appeared only in soil samples from drip (P1) and sprinkle irrigation fields (P5), it was detected in the crops of all farm plots, which demonstrates its ubiquity. The values of the detected fungicides - carbendazim and dimethomorph (P3 and P5) - were compliant with the levels established for lettuce by Regulation (EC) No 396/2005 on 


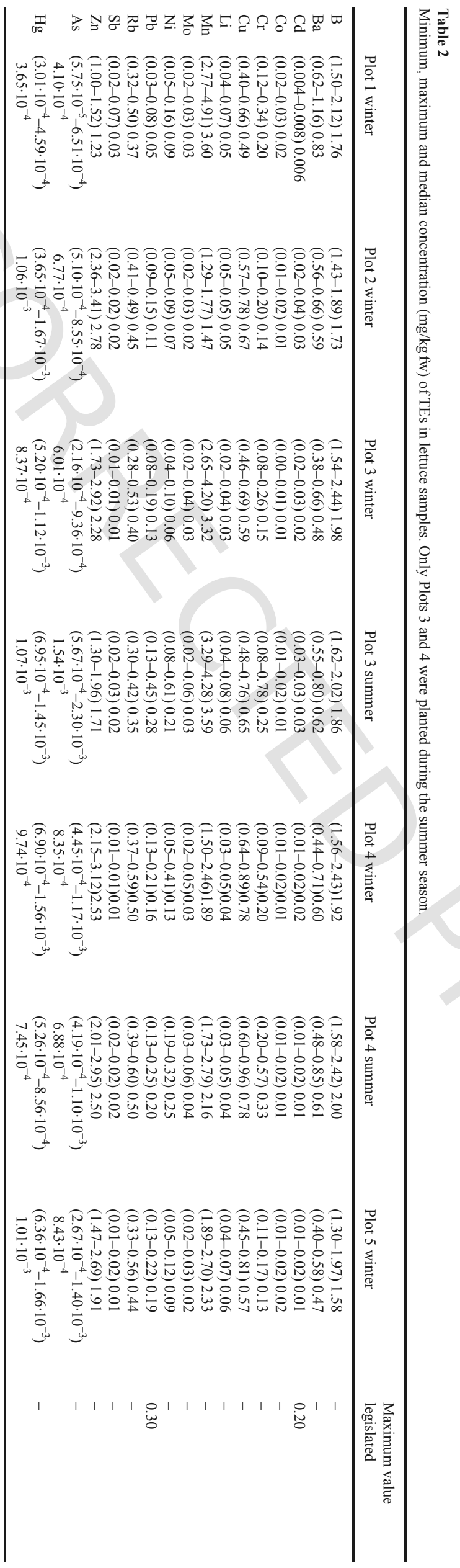


Table 3

Concentration of OMCs (ng/g dw) in soil samples during the summer campaign.

\begin{tabular}{|c|c|c|c|c|c|}
\hline & $\begin{array}{l}\text { Plot } 1 \\
\text { (ng/ } \\
\text { gdw) }\end{array}$ & $\begin{array}{l}\text { Plot } 2 \\
\text { (ng/ } \\
\text { gdw) }\end{array}$ & $\begin{array}{l}\text { Plot } 3 \\
\text { (ng/ } \\
\text { gdw) }\end{array}$ & $\begin{array}{l}\text { Plot } 4 \\
\text { (ng/ } \\
\text { gdw) }\end{array}$ & $\begin{array}{l}\text { Plot } 5 \\
\text { (ng/ } \\
\text { gdw) }\end{array}$ \\
\hline Azoxystrobin & nd & nd & nd & 3.82 & nd \\
\hline Chlorpyrifos & nd & nd & nd & 6.68 & nd \\
\hline $\begin{array}{l}\text { N,N-Diethyl-meta-toluamide } \\
\text { (DEET) }\end{array}$ & 1.40 & $<0.22^{\mathrm{a}}$ & $<0.22$ & 0.48 & 0.56 \\
\hline Diazinon & nd & nd & nd & nd & 3.24 \\
\hline Dimethomorph & nd & nd & 8.96 & nd & 16.9 \\
\hline Surynol 104 & $<0.10$ & $<0.10$ & $<0.10$ & $<0.10$ & $<0.10$ \\
\hline $\begin{array}{l}\text { Tris(2-chloroethyl) phosphate } \\
\text { (TCEP) }\end{array}$ & 1.05 & nd & 0.23 & nd & 2.26 \\
\hline $\begin{array}{l}\text { 2-Mercaptobenzothiazole } \\
(2 \mathrm{MBT})\end{array}$ & $<4.34$ & $<4.34$ & 5.42 & $<4.34$ & $<4.34$ \\
\hline $\begin{array}{l}\text { 5-Methyl-2H-benzotriazole } \\
\text { (5TTri) }\end{array}$ & $<0.12$ & $<0.12$ & $<0.12$ & $<0.12$ & $<0.12$ \\
\hline Bisphenol A (BPA) & $<4.22$ & $<4.22$ & $<4.22$ & $<4.22$ & $<4.22$ \\
\hline Butylparaben & $<0.15$ & nd & nd & nd & 0.28 \\
\hline Bisphenol F (BPF) & 199 & $<9.56$ & 7.91 & $<9.56$ & 106 \\
\hline Benzothiazole & $<4.09$ & $<4.09$ & 7.85 & $<4.09$ & 18.1 \\
\hline Benzotriazole & $<0.41$ & $<0.41$ & 6.75 & $<0.41$ & 12.8 \\
\hline Carbamazepine & $<0.12$ & $<0.12$ & 0.62 & 0.14 & 0.34 \\
\hline Carbendazim & nd & nd & nd & nd & 1.27 \\
\hline Lorazepam & $<5.91$ & nd & $<5.91$ & nd & $<5.91$ \\
\hline Metylparaben (MPB) & $<6.18$ & 29.5 & $<6.18$ & $<6.18$ & 18.3 \\
\hline $\begin{array}{l}\text { 1-Hydroxybenzotriazole } \\
\text { (OHBT) }\end{array}$ & 5.64 & 5.48 & 5.78 & 5.78 & 6.83 \\
\hline Octylphenol & $<0.63$ & $<0.63$ & $<0.63$ & $<0.63$ & $<0.63$ \\
\hline Propylparaben & $<0.19$ & $<0.19$ & $<0.19$ & $<0.19$ & 0.48 \\
\hline Pymetrozin & 1.98 & 1.36 & 2.44 & 1.31 & 2.12 \\
\hline Pyraclostrobin & nd & nd & 0.23 & nd & 2.68 \\
\hline Carbamazepine-10,11-epoxide & nd & $<0.21$ & $<0.21$ & $<0.21$ & $<0.21$ \\
\hline $\begin{array}{l}\text { Tris (chloroisopropyl) } \\
\text { phosphate }(T C P P)\end{array}$ & 397 & $<21.5$ & $<21.5$ & $<21.5$ & 114 \\
\hline
\end{tabular}

$n d=$ not detected, concentration values have been corrected by the recoveries.

${ }^{a}$ Values between LOQ and LOQ are given as $<$ LOD

maximum residue levels of pesticides in food, as the legislated values are about $15 \mathrm{mg} / \mathrm{kg} \mathrm{fw}$ for dimethomorph and $0.1 \mathrm{mg} / \mathrm{kg}$ fw for carbendazim.

\subsubsection{Bioconcentration factors for OMCs}

The BCFs for detected compounds ranged from to 1 to 375 (Table 10-SM). The compounds to show the highest BCFs were carbendazim, due to its direct application as a fungicide (375), and bisphenol F, which is released by the drip irrigation system (200). Except for these two compounds, all other BCF values were in the range of those observed in plants grown in soil but lower than those observed in plants grown under hydroponic conditions (Wu et al., 2015). For instance, in a real field-scale study, Wu et al. (2015) found that carbamazepine had BCF values up to 20 as it is easily transferred from soil to plant, which is in keeping with the values found in the present study (6 to 53). BCFs from crops harvested in summer were lower than those from winter season. This can be explained by the higher lipidic content in summer (Table 5).

\subsection{Effects of the occurrence of chemical pollutants in lettuce}

The chlorophyll, nitrate, lipid, and carbohydrate content of the sampled lettuces were analyzed to evaluate the effects of chemical pollutants in fresh lettuces (Table 5). Lettuces harvested in summer showed statistically higher chlorophyll concentration levels $(p<0.05)$ than those harvested in winter, which can be accounted for by the longer exposure to sunlight during the summer season (Gent, 2014). The concentration of nitrates ranged from 628 to $1854 \mathrm{mg} / \mathrm{kg}$. Although nitrate concentrations in vegetables are considered to be of low toxicity, nitrate is easily reduced to nitrite, which can pose a risk to human health (Guadagnin et al., 2005). The European Union established maximum values for nitrate content in lettuce produced in open fields of $2500 \mathrm{mg} / \mathrm{kg}$ in summer and $4000 \mathrm{mg} / \mathrm{kg}$ in winter (Regulation (EC) No 1881/2006). None of the harvested lettuce showed values above the maximum legislated levels. Since the nitrate concentration in vegetables depends on the harvesting period, agricultural system, maturation stage, and plant part, almost all the sampling sites had a statically different $(p<0.05)$ nitrate content from the other sites. Furthermore, unlike other studies (Guadagnin et al., 2005; Woese et al., 1997), the organic farming plot (P1) was not found to have lower nitrate concentrations. This could support the idea that nitrate content is subject to many factors. For instance, in this study ni-

Table 4

Minimum, maximum and median concentration (ng/g fw) of the OMCs detected in lettuce samples during summer and winter campaigns. Only Plots 3 and 4 were planted during the summer season.

\begin{tabular}{|c|c|c|c|c|c|c|c|}
\hline & Plot 1 winter & Plot 2 winter & Plot 3 winter & Plot 3 summer & Plot 4 winter & Plot 4 summer & Plot 5 winter \\
\hline Dimetomorph & nd & nd & (15.3-20.5) 19.5 & nd & nd & nd & $(0.42-0.62) 0.59$ \\
\hline Surfynol 104 & $<4.07$ & $<4.07$ & $(<4.07-8.10) 7.57$ & $<4.07$ & $<4.07$ & $<4.07$ & $(<4.07-6.77)$ \\
\hline $2 \mathrm{MBT}$ & $(2.39-40.5) 15.3$ & $<0.66$ & $<0.66$ & $<0.66$ & $(<0.66-0.74)$ & $<0.66$ & $(<0.66-1.74) 1.51$ \\
\hline $\mathrm{BPF}$ & $(1.11-1.91) 1.61$ & (1.58-3.92) 3.01 & (17.8-104) 62.0 & $(1.34-3.41) 2.28$ & (15.9-31.2) 22.2 & (13.3-49.6) 15.5 & $(0.59-2.32) 2.16$ \\
\hline Carbamazepine & $(0.18-0.23) 0.20$ & $(0.11-0.13) 0.12$ & $(0.13-0.32) 0.23$ & $(0.33-0.56) 0.36$ & $(0.08-0.18) 0.11$ & $(0.10-0.51) 0.16$ & $(0.13-0.20) 0.14$ \\
\hline Carbendazim & nd & nd & $(<0.24-2.61) 2.24$ & $<0.24$ & nd & nd & $(<0.24-38.9) 19.9$ \\
\hline MPB & $(106-193) 136$ & $(45.2-47.2) 46.4$ & $(24.9-31.9) 28.7$ & $(23.6-31.5) 25.0$ & (25.2-47.9) 31.6 & $(25.8-41.4) 34.9$ & (48.3-83.3) 64.3 \\
\hline Carbamazepine epoxide & $(0.19-0.24) 0.21$ & nd & $(0.05-0.07) 0.06$ & $(0.08-0.10) 0.09$ & (0.08-0.25) 0.16 & 0.09 & $(0.08-0.13) 0.11$ \\
\hline
\end{tabular}

nd= not detected.

Concentration values have been corrected by the recoveries.

Table 5

Minimum, maximum and average levels of different lettuce quality parameters studied $(n=5)$.

\begin{tabular}{|c|c|c|c|c|c|c|c|}
\hline & Plot 1 winter & Plot 2 winter & Plot 3 winter & Plot 3 summer & Plot 4 winter & Plot 4 summer & Plot 5 winter \\
\hline Water content $(\%)$ & 95.0 & 95.3 & 96.1 & 95.2 & 95.7 & 95.2 & 95.8 \\
\hline $\mathrm{Chl}_{\mathrm{T}}\left(\mathrm{mg} / \mathrm{cm}^{2}\right)$ & $(0.40-0.80) 0.58$ & $(0.4-0.7) 0.6$ & $(0.4-0.7) 0.6$ & $(1.1-1.2) 1.2$ & $(0.5-0.6) 0.6$ & $(1.1-1.2) 1.1$ & $(0.2-0.6) 0.4$ \\
\hline Nitrates $(\mathrm{mg} / \mathrm{Kg})$ & $(1113-1543) 1331$ & (729-862) 793 & (1467-1854) 1648 & (1264-1411) 1316 & (739-1039) 843 & $(628-835) 736$ & (1202-1827) 1427 \\
\hline Lipids (\%) & (0.13-0.17) 0.15 & (0.10-0.23) 0.16 & $(0.10-0.16) 0.13$ & (0.22-0.23 0.23 & $(0.13-0.23) 0.20$ & (0.17-0.27) 0.22 & (0.17-0.33) 0.24 \\
\hline Carbohydrates (\%) & $(4.03-4.46) 4.20$ & (3.78-5.53) 4.37 & (3.36-4.23) 3.66 & $(2.76-5.23) 4.20$ & $(4.58-5.94) 5.15$ & $(5.20-6.96) 5.71$ & (4.64-5.43) 5.03 \\
\hline
\end{tabular}


trate content in irrigation waters (Margenat et al., 2017) seemed to be a relevant factor since it was higher in P1, P3, and P5. Fig. 1-SM shows a strong relationship between nitrate content in lettuce and irrigation water (Pearson correlation coefficient of 0.897 and $p$-value $<0.05$ ), which means that the main source of nitrates in crops is plant uptake from irrigation water.

Finally, the lipid and carbohydrate content was analyzed, as the lipid portion has been shown to be a major reservoir for the storage of OMCs (Yang et al., 2016). The concentration of lipids and carbohydrates was shown to be strongly dependent on both the farm plot and the season. Specifically, P4 and P5 had a higher carbohydrate content than the other farm plots studied, and lettuce harvested in summer had higher lipid and carbohydrate content than lettuce harvested in winter (P3). This is consistent with the fact that greater sunlight intensity in summer promotes higher sugar accumulation in plants (Gent, 2014). Furthermore, the results show a negative relationship between nitrate content and sugar content, as has been previously reported for the stabilization of osmotic potential in plant tissues (Blom-Zandstra and Lampe, 1985).

\subsection{Correlation analysis (PCA)}

PCA with Varimax normalized rotation was performed, reducing the 76 measured variables to six principal components with eigenvalues $>1$ explaining $95.7 \%$ of the total variance observed.

The first principal component (PC1), which explains $31.4 \%$ of the variance in the dataset, showed strong positive loadings $(>0.8$, Table 11-SM) for some OMCs in soil (PPB, carbendazim, surfynol 104, BPB, BT, TCEP, dimethomorph), other OMCs in lettuce (carbendazim), TEs in soil ( $\mathrm{Mn}, \mathrm{Rb}, \mathrm{Mg}, \mathrm{Co}, \mathrm{Cr}, \mathrm{Li}$, and $\mathrm{K}$ ), a few TEs in lettuce ( $\mathrm{Li})$, soil moisture, and soil cation-exchange capacity. The positive loadings of these compounds correlated with a high chemical pollution in the soil as well as fungicide application in lettuce (carbendazim); the highest contribution was for the P5 site. This finding indicates that PC1 was associated with pollution.

Another $25.0 \%$ of the variance is explained by the second principal component (PC2), which has high positive loading values (Table 11-SM) for TEs in soil ( $\mathrm{Hg}, \mathrm{Ca}, \mathrm{Na})$, TEs in lettuce $(\mathrm{Hg}, \mathrm{Zn})$, epoxy-10,11-carbamazepine in soil, and total organic carbon (TOC) in soil. This correlated with sampling sites collated in the peri-urban area, where $\mathrm{Na}$ and TOC values are high. Negative loading values were found for MPB in lettuce and TCPP and BPF in soil, which correlates with the control site.

Finally, the third principal component (PC3) explains $19.9 \%$ of the variance in the dataset and has high loadings for soil electrical conductivity, some OMCs in soil (2MBT, carbamazepine, pymetrozin), Mn and carbamazepine in lettuce, and nitrate content in lettuce. This correlates with the impact of reclaimed water (P3), as has previously been determined in the characterization of the irrigation waters (Margenat et al., 2017), a finding that is consistent with the higher soil conductivity and carbamazepine concentration observed in this farm plot.

Fig. 2a shows the three main groups differentiated with regard to the first two PCs. The three main groups are the rural plot (I), P5 (II), and P2-P4 (III). As can be seen, the first differential characteristic depends on the proximity of the sampling site to the urban area. P2-P5 are located in the peri-urban area, whereas P1 is located in a rural area unexposed to urban pollution. However, P5 is impacted by industrial effluents and other soil pollution due to the use of urban biosolids and pesticides. This makes this farm plot the most polluted site. Fig. 2 shows the score plots of PC1 vs PC3. As can be seen, the farm plots from the peri-urban area can be grouped into 3 clusters: a)

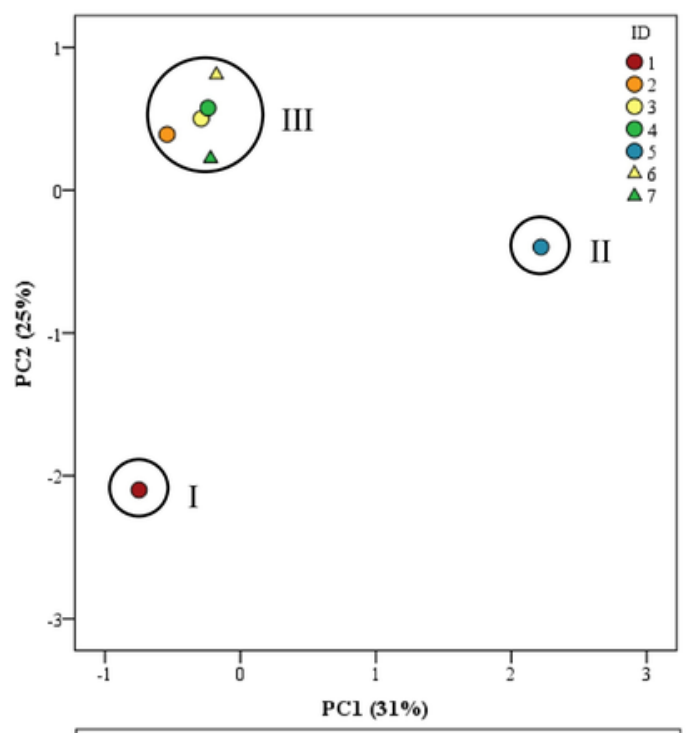

b)

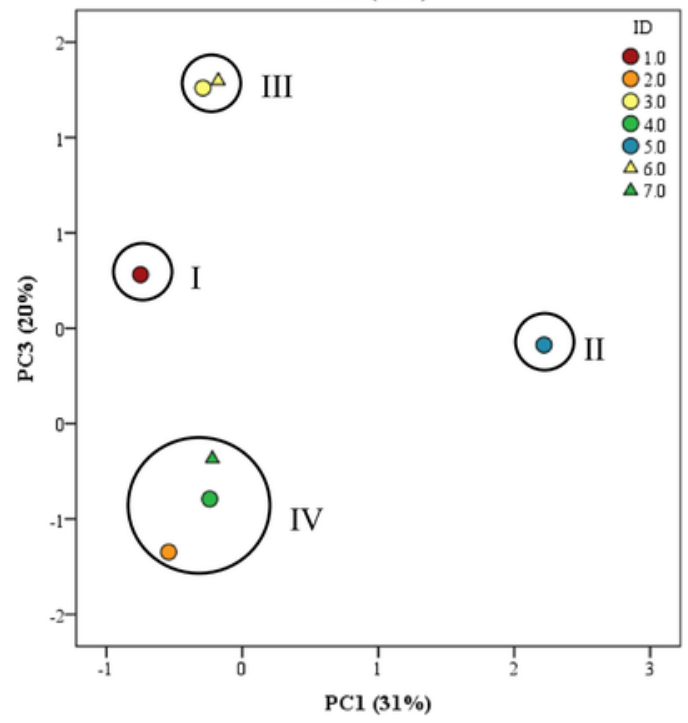

Fig. 2. Principal Component Analysis (PCA) results. a) Scores plot PC1 vs PC2 (ID1 = Plot, ID2=Plot2, ID3=Plot3, ID4=Plot4, ID5=Plot5, ID6=Plot3 summer, ID7= Plot4 summer), b) Scores plot PC1 vs PC3.

the plots irrigated with river water (group IV, P2 and P4), the farm plot irrigated with reclaimed water (group III, P3), and the farm plot irrigated with groundwater (group II, P5). Therefore, the main differences observed in this second score plot (Fig. 2b) with regard to pollution (organic and inorganic) in soil and lettuce are due to the quality of the irrigation water.

\section{Conclusions}

The results of this study demonstrate that peri-urban pollution increases the occurrence of pollutants, but does not affect lipid and carbohydrate content.

- The concentrations of TEs and OMCs ranged from 0.79 to $802.5 \mathrm{mg} / \mathrm{kg} \mathrm{dw}$ and from $<0.1$ to $397 \mathrm{ng} / \mathrm{g} \mathrm{dw}$, respectively, in the peri-urban soil, whereas they ranged from $6 \cdot 10^{-5}$ to $4.91 \mathrm{mg} / \mathrm{kg} \mathrm{fw}$ and from $<0.1$ to $193 \mathrm{ng} / \mathrm{g} \mathrm{fw}$, respectively, in the lettuce crops.

- The concentrations of metals in the soil from the rural area were always below the Catalonian guidelines, but limits were exceeded 
for $\mathrm{Mo}, \mathrm{Ni}, \mathrm{Pb}$, and $\mathrm{As}$ in the soils of the peri-urban area. However, their occurrence in lettuce complied with human food safety standards (except for $\mathrm{Pb}$ in peri-urban area),

- The many fungicides (carbendazim, dimetomorph, and MPB) and chemicals released by plastic pipelines (TCPP, BPF, and 2-MBT) used in agriculture were prevalent in the soil or the edible parts of the lettuce. In contrast, chemicals from irrigation waters (carbamazepine, surfynol 104) were not.

- The BCFs of TEs ranged from 0.0002 to 1.78 , whereas for OMCs such as pesticides and plastic-related compounds it depended on whether or not they came into direct or indirect (use of plastic pipelines) contact with the lettuce leaf surface.

- Chlorophyll, lipid, and carbohydrate content in crops grown in the peri-urban area were not affected by soil or irrigation water pollution, whereas nitrate content depended on the irrigation water quality.

- PCA showed that peri-urban pollution and water irrigation quality could explain a large share of the variance in the dataset.

Although the present study showed that lettuce exposure to peri-urban pollution did not affect lipid and carbohydrate content, further studies are necessary to assess changes in agri-food quality associated with peri-urban pollution. Similarly, further work is needed on the potential effects of chemical pollutants released by plastic irrigation pipes on crops.

\section{Uncited references}

$$
\begin{aligned}
& \text { AOAC, } 1997 \\
& \text { EC, } 2005 \\
& \text { EC, } 2006 \\
& \text { FAO, n.d }
\end{aligned}
$$

\section{Acknowledgments}

The authors gratefully acknowledge the financial support of the Spanish Ministry of Economy, Industry, and Competitiveness (MEIC) through Project AGL2014-59353-R. A. M. and Dr. V. M. would also like to acknowledge an FPI fellowship (BES-2015-075745) and a Ramon y Cajal contract (RYC-2013-12522) from the MEIC. The authors would further like to thank the officers and farmers of the Baix Llobregat Agrarian Park for their assistance, as well as Ms. Yolanda Rodríguez, Ms. Alessandra Fiorillo, and Mr. Manel Martín for their technical assistance with the sampling and sample preparation.

\section{Appendix A. Supplementary data}

Supplementary data to this article can be found online at https:// doi.org/10.1016/j.scitotenv.2018.05.035.

\section{References}

Alloway, B.J., 2012. Heavy metals in soils: trace metals and metalloids in soils and their bioavailability. Environ. Pollut. https://doi.org/10.1007/978-94-007-4470-7.

AOAC, 1997. Official methods of analysis of the Association of Official Analytical Chemists. In: Method 976, 16th ed., 14, AOAC International, Gaithersburg, MD USA, (3rd revn).

Becerra-Herrera, M., Miranda, V., Arismendi, D., Richter, P., 2018. Chemometric optimization of the extraction and derivatization of parabens for their determination in water samples by rotating-disk sorptive extraction and gas chromatography mass spectrometry. Talanta 176, 551-557. https://doi.org/10.1016/j.talanta.2017. 08.071.

Blom-Zandstra, M., Lampe, J.A.N.E.M., 1985. The Role of Nitrate in the Osmoregulation of Lettuce (Lactuca sativa L.) Grown at Different Light Intensities. 36, 1043-1052.
Calderón-Preciado, D., Jiménez-Cartagena, C., Peñuela, G., Bayona, J.M., 2009. Development of an analytical procedure for the determination of emerging and priority organic pollutants in leafy vegetables by pressurized solvent extraction followed by GC-MS determination. Anal. Bioanal. Chem. 394, 1319-1327. https:// doi.org/10.1007/s00216-009-2669-0.

Calderón-Preciado, D., Jiménez-Cartagena, C., Matamoros, V., Bayona, J.M., 2011. Screening of 47 organic microcontaminants in agricultural irrigation waters and their soil loading. Water Res. 45, 221-231. https://doi.org/10.1016/j.watres.2010. 07.050 .

Calvo-Flores, F.G., Isac-Garcéa, J., Dobado, J.A., 2018. Personal-care products. In: Emerging Pollutants: Origin, Structure and Properties. Wiley-VCH Verlag GmbH \& Co. KGaA, pp. 385-422. https://doi.org/10.1002/9783527691203.ch11.

Carter, L.J., Williams, M., Böttcher, C., Kookana, R.S., 2015. Uptake of pharmaceuticals influences plant development and affects nutrient and hormone homeostases. Environ. Sci. Technol. 49, 12509-12518. https://doi.org/10.1021/acs.est.5b03468.

Castro, E., Mañas, M.P., De Las Heras, J., 2009. Nitrate content of lettuce (Lactuca sativa L.) after fertilization with sewage sludge and irrigation with treated wastewater. Food Addit. Contam. Part A Chem. Anal. Control Expo. Risk Assess 26, 172-179. https://doi.org/10.1080/02652030802425334.

Chang, C.Y., Yu, H.Y., Chen, J.J., Li, F.B., Zhang, H.H., Liu, C.P., 2014. Accumulation of heavy metals in leaf vegetables from agricultural soils and associated potential health risks in the Pearl River Delta, South China. Environ. Monit. Assess 186, 1547-1560. https://doi.org/10.1007/s10661-013-3472-0.

Christou, A., Karaolia, P., Hapeshi, E., Michael, C., Fatta-Kassinos, D., 2017. Long-term wastewater irrigation of vegetables in real agricultural systems: concentration of pharmaceuticals in soil, uptake and bioaccumulation in tomato fruits and human health risk assessment. Water Res. 119, 312. https://doi.org/10.1016/j. watres.2017.04.065.

Colon, B., Toor, G.S., 2016. A review of uptake and translocation of pharmaceuticals and personal care products by food crops irrigated with treated wastewater. In: Advances in Agronomy. Elsevier Inc.https://doi.org/10.1016/bs.agron.2016.07.001.

Daughton, C.G., Ternes, T.A., 1999. Pharmaceuticals and personal care products in the environment. Environ. Toxicol. 107, 907-938. https://doi.org/10.1021/ bk-2001-0791.

Davis, H.T., Marjorie Aelion, C., McDermott, S., Lawson, A.B., 2009. Identifying natural and anthropogenic sources of metals in urban and rural soils using GIS-based data, PCA, and spatial interpolation. Environ. Pollut. 157, 2378-2385. https://doi. org/10.1016/j.envpol.2009.03.021.

EC, 2005. Regulation (EC) NO 396/2005 of the European Parliament and of the Council of 23 February 2005 on Maximum Residue Levels of Pesticides in or on Food and Feed of Plant and Animal Origin and Amending Council Directive 91/414/ EEC.

EC, 2006. Commission Regulation (EC) No. 1881/2006 of 19 December 2006 Setting Maximum Levels for Certain Contaminants in Foodstuffs.

Eggen, T., Lillo, C., 2012. Antidiabetic II drug metformin in plants: uptake and translocation to edible parts of cereals, oily seeds, beans, tomato, squash, carrots, and potatoes. J. Agric. Food Chem. 60, 6929-6935. https://doi.org/10.1021/ jf301267c.

Esturk, O., Yakar, Y., Ayhan, Z., 2014. Pesticide residue analysis in parsley, lettuce and spinach by LC-MS/MS. J. Food Sci. Technol. 51, 458-466. https://doi.org/10. 1007/s13197-011-0531-9.

FAO, Codex Alimentarius. In: http://www.fao.org/fao-who-codexalimentarius/ codex-texts/guidelines/en/Accessed 16 April 2018.

Gaweda, M., 2007. Changes in the contents of some carbohydrates in vegetables cumulating lead. Pol. J. Environ. Stud. 16, 57-62.

Generalitat de Catalunya, 2017. LLEI 5/2017, del 28 de març, de mesures fiscals, administratives, financeres i del sector públic i de creació i regulació dels impostos sobre grans establiments comercials, sobre estades en establiments turístics, sobre elements radiotòxics, sobre begudes. In: Diari Oficial de la Generalitat de Catalunya.

Gent, M.P.N., 2014. Effect of daily light integral on composition of hydroponic lettuce. Hortscience 49, 173-179.

Guadagnin, S.G., Rath, S., Reyes, F.G.R., 2005. Evaluation of the nitrate content in leaf vegetables produced through different agricultural systems. Food Addit. Contam. 22, 1203-1208. https://doi.org/10.1080/02652030500239649.

Hurtado, C., Parastar, H., Matamoros, V., Piña, B., Tauler, R., Bayona, J.M., 2017. Linking the morphological and metabolomic response of Lactuca sativa $\mathrm{L}$ exposed to emerging contaminants using $\mathrm{GC} \times \mathrm{GC}-\mathrm{MS}$ and chemometric tools. Sci. Rep. 7, 6546. https://doi.org/10.1038/s41598-017-06773-0.

Inskeep, W.P., Bloom, P.R., 1985. Extinction coefficients of chlorophyll a and b in N,N-dimethylformamide and $80 \%$ acetone. Plant Physiol. 77, 483-485. https://doi. org/10.1104/pp.77.2.483.

Khan, S., Cao, Q., Zheng, Y.M., Huang, Y.Z., Zhu, Y.G., 2008. Health risks of heavy metals in contaminated soils and food crops irrigated with wastewater in Beijing, China. Environ. Pollut. 152, 686-692. https://doi.org/10.1016/j.envpol.2007.06. 056.

Kos, B., Grčman, H., Leštan, D., 2003. Phytoextraction of lead, zinc and cadmium from soil by selected plants. Plant Soil Environ. 49, 548-553.

Lee, C.S.L., Li, X., Shi, W., Cheung, S.C.N., Thornton, I., 2006. Metal contamination in urban, suburban, and country park soils of Hong Kong: a study based on GIS 
and multivariate statistics. Sci. Total Environ. 356, 45-61. https://doi.org/10.1016/ j.scitotenv.2005.03.024

Liacos, J.W., Kam, W., Delfino, R.J., Schauer, J.J., Sioutas, C., 2012. Characterization of organic, metal and trace element PM2.5 species and derivation of freeway-based emission rates in Los Angeles, CA. Sci. Total Environ. 435-436, 159-166. https://doi.org/10.1016/j.scitotenv.2012.06.106.

Lough, G.C., Schauer, J.J., Park, J.S., Shafer, M.M., Deminter, J.T., Weinstein, J.P., 2005. Emissions of metals associated with motor vehicle roadways. Environ. Sci. Technol. 39, 826-836. https://doi.org/10.1021/es048715f.

Mac Loughlin, T.M., Peluso, L., Marino, D.J.G., 2017. Pesticide impact study in the peri-urban horticultural area of Gran La Plata, Argentina. Sci. Total Environ. 598, 572-580. https://doi.org/10.1016/j.scitotenv.2017.04.116.

Malchi, T., Maor, Y., Tadmor, G., Shenker, M., Chefetz, B., 2014. Irrigation of Root Vegetables with Treated Wastewater: Evaluating Uptake of Pharmaceuticals and the Associated Human Health Risks. https://doi.org/10.1021/es5017894.

Marcé, R., Honey-Rosés, J., Manzano, A., Moragas, L., Catllar, B., Sabater, S., 2012. The Llobregat River Basin: a paradigm of impaired rivers under climate change threats. In: Sabater, S., Ginebreda, A., Barceló, D. (Eds.), The Llobregat: The Story of a Polluted Mediterranean River. Springer, Berlin Heidelberg, Berlin, Heidelberg, pp. 1-26. https://doi.org/10.1007/698 2012152.

Margenat, A., Matamoros, V., Díez, S., Cañameras, N., Comas, J., Bayona, J.M., 2017. Occurrence of chemical contaminants in peri-urban agricultural irrigation waters and assessment of their phytotoxicity and crop productivity. Sci. Total Environ. 599-600, 1140-1148. https://doi.org/10.1016/j.scitotenv.2017.05.025.

McBride, M.B., Shayler, H.A., Spliethoff, H.M., Mitchell, R.G., Marquez-Bravo, L.G., Ferenz, G.S., Russell-Anelli, J.M., Casey, L., Bachman, S., 2014. Concentrations of lead, cadmium and barium in urban garden-grown vegetables: the impact of soil variables. Environ. Pollut. 194, 254-261. https://doi.org/10.1016/j.envpol.2014.07. 036.

Monteiro, M., Santos, C., Mann, R.M., Soares, A.M.V.M., Lopes, T., 2007. Evaluation of cadmium genotoxicity in Lactuca sativa L. using nuclear microsatellites. Environ. Exp. Bot. 60, 421-427. https://doi.org/10.1016/j.envexpbot.2006.12.018.

Nabulo, G., Oryem-Origa, H., Diamond, M., 2006. Assessment of lead, cadmium, and zinc contamination of roadside soils, surface films, and vegetables in Kampala City, Uganda. Environ. Res. 101, 42-52. https://doi.org/10.1016/j.envres.2005.12. 016 .

Nabulo, G., Young, S.D., Black, C.R., 2010. Assessing risk to human health from tropical leafy vegetables grown on contaminated urban soils. Sci. Total Environ. 408, 5338-5351. https://doi.org/10.1016/j.scitotenv.2010.06.034.

Pan, M., Wong, C.K.C., Chu, L.M., 2014. Distribution of antibiotics in wastewater-irrigated soils and their accumulation in vegetable crops in the Pearl River Delta, Southern China. J. Agric. Food Chem. 62, 11062-11069. https://doi.org/10.1021/ jf503850v.

Paül, V., McKenzie, F.H., 2013. Peri-urban farmland conservation and development of alternative food networks: insights from a case-study area in metropolitan Barcelona (Catalonia, Spain). Land Use Policy 30, 94-105. https://doi.org/10. 1016/j.landusepol.2012.02.009.

Pedrero, F., Kalavrouziotis, I., Alarcón, J.J., Koukoulakis, P., Asano, T., 2010. Use of treated municipal wastewater in irrigated agriculture-review of some practices in Spain and Greece. Agric. Water Manag. 97, 1233-1241. https://doi.org/10.1016/j. agwat.2010.03.003

Peralta-Videa, J.R., Lopez, M.L., Narayan, M., Saupe, G., Gardea-Torresdey, J., 2009. The biochemistry of environmental heavy metal uptake by plants: implications for the food chain. Int. J. Biochem. Cell Biol. 41, 1665-1677. https://doi.org/10.1016/ j.biocel.2009.03.005.

Porra, R., 2002. The chequered history of the development and use of simultaneous equations for the accurate determination of chlorophylls a and b. Photosynth. Res. 73, 149-156. https://doi.org/10.1023/a:1020470224740.

Regueiro, J., Wenzl, T., 2015. Determination of bisphenols in beverages by mixed-mode solid-phase extraction and liquid chromatography coupled to tandem mass spectrometry. J. Chromatogr. A 1422, 230-238. https://doi.org/10.1016/j. chroma.2015.10.046.

Riemenschneider, C., Al-Raggad, M., Moeder, M., Seiwert, B., Salameh, E., Reemtsma, T., 2016. Pharmaceuticals, their metabolites, and other polar pollutants in field-grown vegetables irrigated with treated municipal wastewater. J. Agric. Food Chem. 64, 5784-5792. https://doi.org/10.1021/acs.jafc.6b01696.

Rodríguez-Serrano, M., Romero-Puertas, M.C., Zabalza, A., Corpas, F.J., Gómez, M. Del Río, L.A., Sandalio, L.M., 2006. Cadmium effect on oxidative metabolism of pea (Pisum sativum L.) roots. Imaging of reactive oxygen species and nitric oxide accumulation in vivo. Plant Cell Environ. 29, 1532-1544. https://doi.org/10.1111/ j.1365-3040.2006.01531.x.

Santamaria, P., 2006. Nitrate in vegetables: toxicity, content, intake and EC regulation. J. Sci. Food Agric. 86, 10-17. https://doi.org/10.1002/jsfa.2351.

Singh, S., Kumar, M., 2006. Heavy metal load of soil, water and vegetables in peri-urban Delhi. Environ. Monit. Assess. 120, 79-91, https://doi.org/10.1007/ s10661-005-9050-3.

United States Department of Agriculture, 1987. USDA Textural Soil Classification. Soil Mech. Lev. I Modul. 3 - USDA Textural Soil Classif.

Van Veenhuizen, R., 2007. Profitability and Sustainability of Urban and Periurban Agriculture.

WHO, 1989. Health Guidelines for the Use of Wastewater in Agriculture and Aquaculture: Report of a WHO Scientific Group [Meeting Held in Geneva from 18 to 23 November 1987].

Woese, K., Lange, D., Boess, C., Bögl, K.W., 1997. A comparison of organically and conventionally grown foods-results of a review of the relevant literature. J. Sci. Food Agric. 74, 281-293. https://doi.org/10.1002/(SICI)1097-0010(199707)74 $3<281::$ AID-JSFA794>3.0.CO;2-Z

Wu, X., Conkle, J.L., Ernst, F., Gan, J., 2014. Treated wastewater irrigation: uptake of pharmaceutical and personal care products by common vegetables under field conditions. Environ. Sci. Technol. 48, 11286-11293. https://doi.org/10.1021/ es502868k

Wu, X., Dodgen, L.K., Conkle, J.L., Gan, J., 2015. Plant uptake of pharmaceutical and personal care products from recycled water and biosolids: a review. Sci. Total Environ. 536, 655-666. https://doi.org/10.1016/j.scitotenv.2015.07.129.

Xu, J., Wu, L., Chen, W., Chang, A.C., 2008. Simultaneous determination of pharmaceuticals, endocrine disrupting compounds and hormone in soils by gas chromatography-mass spectrometry. J. Chromatogr. A 1202, 189-195. https://doi.org/ 10.1016/j.chroma.2008.07.001

Yang, C.Y., Chang, M. Ling, Wu, S.C., Shih, Y. Hsin, 2016. Sorption equilibrium of emerging and traditional organic contaminants in leafy rape, Chinese mustard, lettuce and Chinese cabbage. Chemosphere 154, 552-558. https://doi.org/10.1016/j. chemosphere.2016.03.111.

Zimakowska-Gnoińska, D., Bech, J., Francisco, J., Nska, D.Z., 2000. Assessment of the Heavy Metal Pollution Effects on the Soil Respiration in the Baix Llobregat (Catalonia, Ne Spain). 1, 301-313. 